\title{
Formation of submarine gas hydrates
}

\author{
V. SOLOVIEV \& G. D. GINSBURG
}

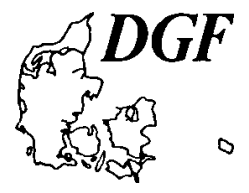

Soloviev, V. \& Ginsburg, G.D.: Formation of submarine gas hydrates. Bulletin of the Geological Society of Denmark, Vol. 41, pp. 86-94. Copenhagen, 1994-03-30. https://doi.org/10.37570/bgsd-1995-41-09

\begin{abstract}
Submarine gas hydrates have been discovered in the course of deep-sea drilling (DSDP and ODP) and bottom sampling in many offshore regions. This paper reports on expeditions carried out in the Black, Caspian and Okhotsk Seas. Gas hydrate accumulations were discovered and investigated in all these areas. The data and an analysis of the results of the deep-sea drilling programme suggest that the infiltration of gas-bearing fluids is a necessary condition for gas hydrate accumulation. This is confirmed by geological observations at three scale levels. Firstly, hydrates in cores are usually associated with comparatively coarse-grained, permeable sediments as well as voids and fractures. Secondly, hydrate accumulations are controlled by permeable geological structures, i.e. faults, diapirs, mud volcanos as well as layered sequences. Thirdly, in the worldwide scale, hydrate accumulations are characteristic of continental slopes and rises and intra-continental seas where submarine seepages also are widespread. Both biogenic and cat-agenic gas may occur, and the gas sources may be located at various distances from the accumulation. Gas hydrates presumably originate from water-dissolved gas. The possibility of a transition from dissolved gas into hydrate is confirmed by experimental data. Shallow gas hydrate accumulations associated with gas-bearing fluid plumes are the most convenient features for the study of submarine hydrate formation in general. These accumulations are known from the Black, Caspian and Okhotsk Seas, the Gulf of :Mexico and off northern California.
\end{abstract}

V. Soloviev \& G. D. Ginsburg, Research Institute for Geology and Mineral Resources of the Ocean "VNIIOkeangeologia". pr.Maklina 1, St. Petersburg 190121, Russia August 23rd, 1992.

\section{Introduction}

More than forty regions are known today where gas hydrates have been discovered or where they may be inferred from indirect evidence (Fig. 1). Submarine gas hydrates have been discovered in the course of deep-sea drilling and bottom sampling in the Caspian Sea (Efremova et al. 1979; Ginsburg et al. 1988), Black Sea (Efremova \& Zhizhchenko 1974; Ginsburg et al. 1990), Okhotsk Sea (Zonenshain et al. 1987; Ginsburg et al. 1993) Japan Sea (Shipboard Scientific Party 1990), Gulf of Mexico (Brooks et al. 1984), Blake - Outer Ridge (Kvenvolden \& Barnard 1983) and on the slopes of the following deep-sea trenches: Middle-American (Shipley \& Didyk 1982; Harrison \& Curiale 1982; Kvenvolden \& McDonald 1985), Peruvian (Kvenvolden \& Kastner 1990) and Nankai (Shipboard Scientific Party 1991). All gas hydrate regions are associated with sedimentary basins with young, thick, rapidly accumulating sedimentary cover on continental slopes, rises and in intra-continental seas. However, the origins of gas hydrates are poorly understood.

Gas hydrate formation is believed to be a common geological phenomenon occurring under deep-water conditions, although only under certain geological conditions. The elucidation of the geological significance of submarine gas hydrate formation is of undoubted interest, since it is associated with alteration of the overall state of fluids in the sediments.

The aims of this paper are to investigate the most favourable conditions for gas hydrate formation in marine sediments and to describe its common features based on our cruise and experimental data and on deep-sea drilling studies.

\section{Experimental data}

The possibility of gas hydrate formation from waterdissolved gas is confirmed by experimental data. The solubility of gas in water in equilibrium with hydrate is limited by the equilibrium pressure of hydrate formation at a given temperature rather than by hydrostatic pressure (Makogon \& Davidson 1983). The lower the temperature, the lower is the equilibrium pressure and, correspondingly, the gas solubility. Formation of gas hydrates from dissolved gas under static conditions has been experimentally proved (Namiot \& Gorodetskaya 1969). For this paper the mechanism of gas hydrate formation from gas dissolved in flowing water has been tested (Mashirov et al. 1991). Freon-12 $\left(\mathrm{CF}_{2} \mathrm{Cl}_{2}\right)$ was used as the hydrate- 
Fig. 1. Gas hydrate locations in the Ocean. Gas hydrate observation: 1 - deep sea drilling, 2 - bottom sampling; geochemical indications: 3 - low chlorinity of pore water, 4 gassy cores; geophysical indications: 5 - logging data; 6 - seismic survey data.

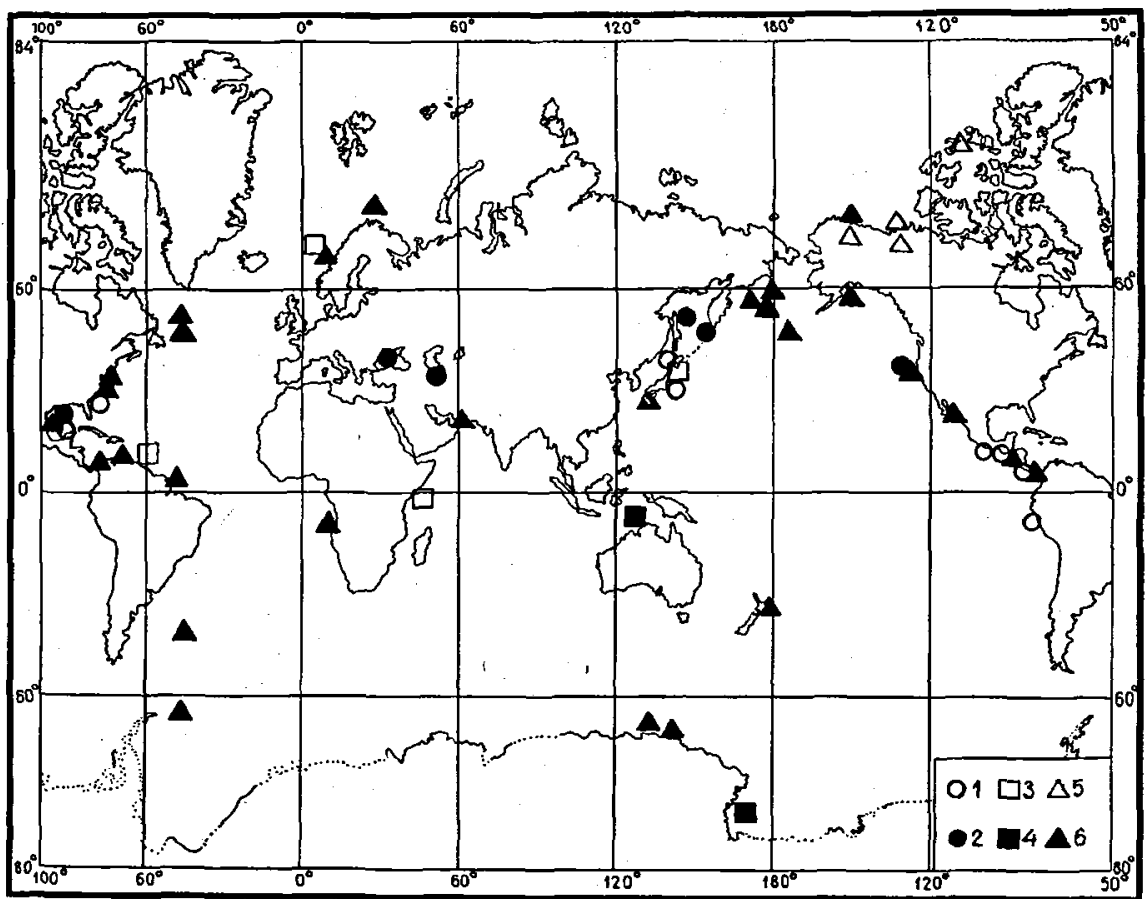

forming gas. The low dissociation pressure of freon-12 hydrate in comparison with hydrate of natural gas pro-

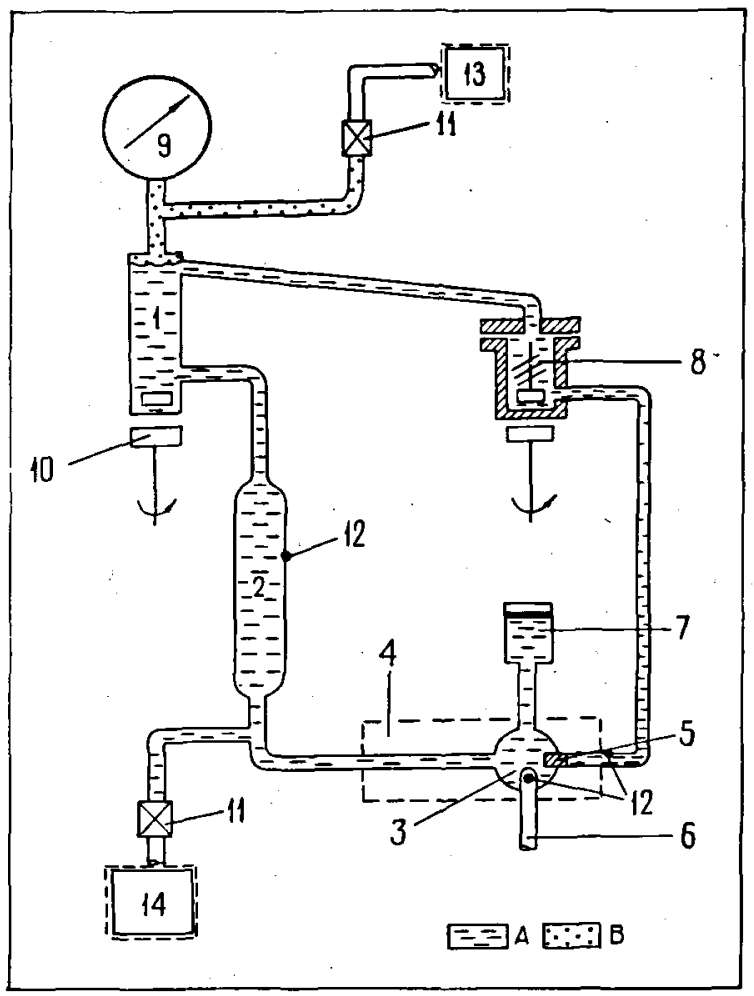

vided better conditions for the experiment. Moreover, like hydrocarbon gases, freon-12 hydrate is hydrophobic.

Fig. 2 shows the arrangement of the experimental equipment. The vessel for water saturation with gas (1) and the reaction vessel (2) are the main items. The experimental conditions were as follows: $\mathrm{P}=200 \mathrm{kPa}$; T1 $=$ $284.9^{\circ} \mathrm{K} ; \mathrm{P} 1=432 \mathrm{kPa} ; \mathrm{T} 2=274.3^{\circ} \mathrm{K} ; \mathrm{P} 2=46.5 \mathrm{kPa}$ where $\mathrm{P}$ is the gas pressure in the plant during the time of water saturation with gas and the beginning of gas hydrate formation. $\mathrm{T} 1$ is the temperature in the saturation vessel; $\mathrm{P} 1$ is the equilibrium pressure of freon- 12 hydrate formation at $\mathrm{T} 1 ; \mathrm{T} 2$ is the temperature in reaction vessel and $\mathrm{P} 2$ is the equilibrium pressure of freon-12 hydrate formation at $\mathrm{T} 2$.

As a result of the experiment the freon- 12 hydrate was obtained in the reaction vessel directly from aqueous solution. Gas hydrate formation was observed visually and pressure in the plant was decreased from 200 to 170 $\mathrm{kPa}$ (Fig. 3). Oversaturation of the water with gas in the reaction vessel was 3.4 at $\mathrm{P}=200 \mathrm{kPa}$ at the beginning of gas hydrate formation and 2.9 at $\mathrm{P}=170 \mathrm{pKa}$ at the end of the experiment.

Fig. 2. Scheme of the experimental set. 1 - vessel for water saturation with gas, 2 - buffer volume for gas separation, 3 reaction vessel, 4 - refrigerator-thermostat, 5 - filter, 6 - glass finger, 7 -gas-collector, 8 - magnetic pump, 9 - pressure gauge, 10 - magnetic mixer, 11 - valves, 12 - resistance thermometer, 13 - system for gas pumping, 14 - system for filling with solution; A - liquid phase; B - gaseous phase. 


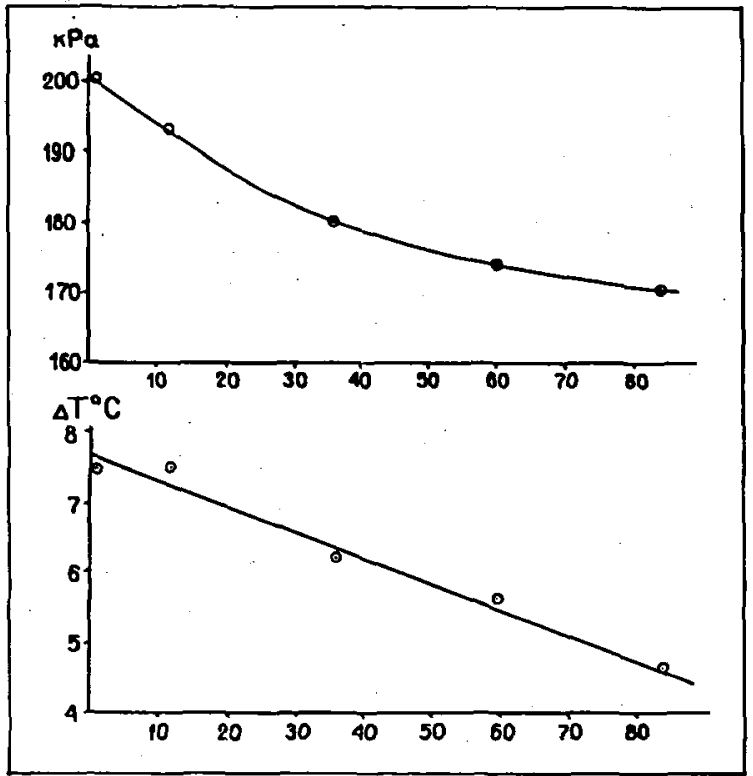

Fig. 3. Plot of pressure $(\mathrm{P}, \mathrm{kPa})$ and difference between temperature of thermostat and temperature behind reaction vessel $(\Delta \mathrm{T}$, ${ }^{\circ} \mathrm{C}$ ) vs. gas hydrate formation time (hours)

\section{Observational data}

\section{The Caspian Sea}

Specific features of the southern Caspian Sea are the thick Cenozoic sedimentary cover, high oil and gas potential and the wide distribution of clay diapirism and mud volcanism. More than fifty mud volcanoes are thought to occur in deep-water areas of the sea (Fig. 4)

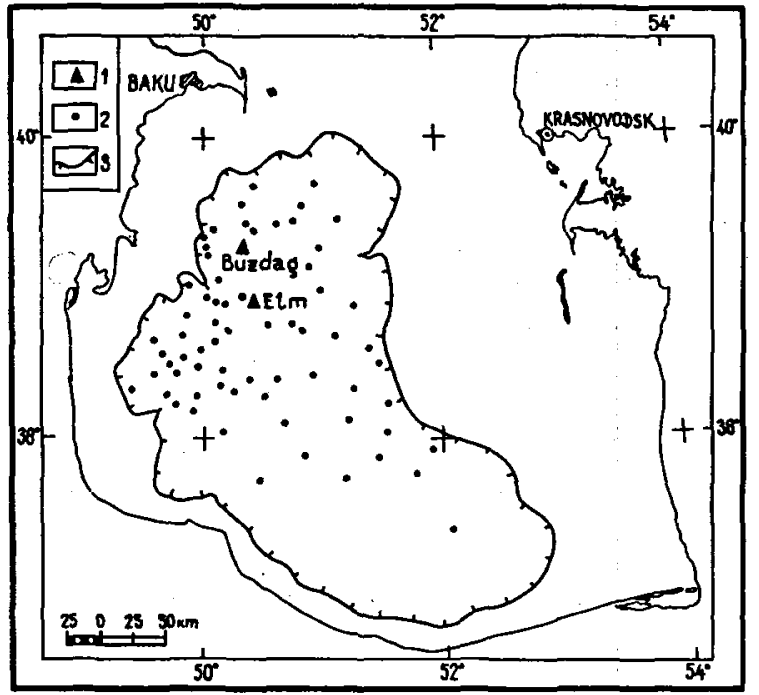

Fig. 4. Gas hydrate accumulations in the deep southern Caspian Sea. 1 - detected gas hydrate accumulations at the mud volcanoes, 2 - submarine mud volcanoes, 3 -limit of the potential gas hydrate prone area.

and gas hydrate accumulations associated with these mud volcanoes have been discovered (Efremova et al. 1979; Ginsburg et al. 1988). Diapiric structures and mud volcanoes are clearly displayed on medium frequency seismic records (Fig. 5).

Gas hydrates were observed in two mud volcanic crater fields in a clay breccia, one occurrence being immediately on the sea bottom. The hydrate inclusions in the breccia were up to $5 \mathrm{~cm}$ and of various shapes of which the most common were subisometric, though sometimes thin plates were observed. The hydrate content in the

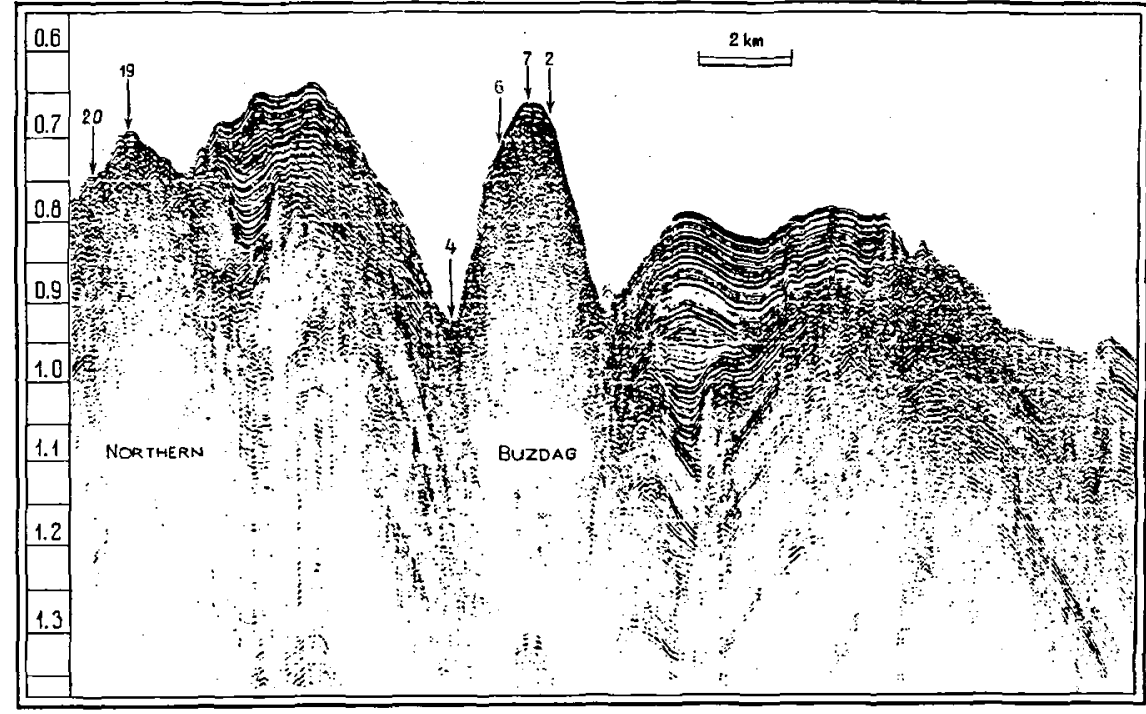

Fig. 5. Seismic profile across the Vezirov Rise (Shatsky Ridge). Arrows indicate sampling stations; the left scale is two-way traveltime (s). 
Table 1. Composition of gas from the gas hydrates.

\begin{tabular}{|c|c|c|c|c|c|c|c|c|c|c|c|c|c|}
\hline \multirow{2}{*}{ Region } & \multirow{2}{*}{ Area } & \multirow{2}{*}{$\begin{array}{c}\mathrm{\Sigma} \mathrm{C}_{\mathrm{n}}+\mathrm{CO}_{2} \\
\%\end{array}$} & \multicolumn{7}{|c|}{ Composition of gas, $\%$ from $\Sigma\left(\mathrm{C}_{\mathrm{n}}+\mathrm{CO}_{2}\right)$} & \multicolumn{4}{|c|}{$\delta^{13} \mathrm{C}, \%$} \\
\hline & & & $\mathrm{C}_{1}$ & $\mathrm{C}_{2}$ & $\mathrm{C}_{3}$ & $\mathrm{iC}_{4}$ & $\mathrm{nC}_{4}$ & $\mathrm{C}_{5+}$ & $\mathrm{CO}_{2}$ & $\mathrm{C}_{1}$ & $\mathrm{C}_{2}$ & $\mathrm{C}_{3}$ & $\mathrm{C}_{4}$ \\
\hline \multirow[t]{2}{*}{$\begin{array}{l}\text { Caspian } \\
\text { Sea }\end{array}$} & $\begin{array}{l}\text { Buzdag, mud } \\
\text { volcano }\end{array}$ & $\begin{array}{l}99.0 \\
93.4\end{array}$ & $\begin{array}{l}74.7 \\
76.0\end{array}$ & $\begin{array}{l}17.4 \\
19.3\end{array}$ & $\begin{array}{l}2.4 \\
2.4\end{array}$ & $\begin{array}{l}0.4 \\
0.6\end{array}$ & $\begin{array}{l}1.1 \\
0.3\end{array}$ & $\begin{array}{l}0.33 \\
0.05\end{array}$ & $\begin{array}{l}3.6 \\
1.2\end{array}$ & $\begin{array}{c}-44.8 \\
\text { n.a. }\end{array}$ & $\begin{array}{l}-26.0 \\
\text { n.a. }\end{array}$ & $\begin{array}{l}-22.1 \\
\text { n.a. }\end{array}$ & $\begin{array}{l}-20.9 \\
\text { n.a. }\end{array}$ \\
\hline & $\begin{array}{l}\text { Elm, mud } \\
\text { volcano }\end{array}$ & $\begin{array}{l}99.5 \\
43.0\end{array}$ & $\begin{array}{l}95.3 \\
81.4\end{array}$ & $\begin{array}{r}0.6 \\
15.3\end{array}$ & $\begin{array}{l}1.6 \\
1.6\end{array}$ & $\begin{array}{l}1.7 \\
0.2\end{array}$ & $\begin{array}{l}\text { n.d. } \\
0.7\end{array}$ & $\begin{array}{l}0.01 \\
\text { n.d. }\end{array}$ & $\begin{array}{l}0.9 \\
0.8\end{array}$ & $\begin{array}{l}-56.0 \\
\text { n.a. }\end{array}$ & $\begin{array}{l}-27.0 \\
\text { n.a. }\end{array}$ & $\begin{array}{l}-7.8 \\
\text { n.a. }\end{array}$ & $\begin{array}{l}-30.8 \\
\text { n.a. }\end{array}$ \\
\hline $\begin{array}{l}\text { Black } \\
\text { Sea }\end{array}$ & $\begin{array}{l}\text { offshore } \\
\text { the Crimea }\end{array}$ & $\begin{array}{l}98.2 \\
99.2\end{array}$ & $\begin{array}{l}99.1 \\
99.1\end{array}$ & $\begin{array}{l}0.02 \\
0.04\end{array}$ & $\begin{array}{l}2 \cdot 10^{-4} \\
4 \cdot 10^{-4}\end{array}$ & $\begin{array}{l}\text { n.a. } \\
\text { n.a. }\end{array}$ & $\begin{array}{l}\text { n.a. } \\
\text { n.a. }\end{array}$ & $\begin{array}{l}\text { n.a. } \\
\text { n.a. }\end{array}$ & $\begin{array}{l}0.9 \\
0.9\end{array}$ & $\begin{array}{l}-61.8 \\
-63.4\end{array}$ & $\begin{array}{l}\text { n.a. } \\
\text { n.a. }\end{array}$ & $\begin{array}{l}\text { n.a. } \\
\text { n.a. }\end{array}$ & $\begin{array}{l}\text { n.a. } \\
\text { n.a. }\end{array}$ \\
\hline \multirow[t]{2}{*}{$\begin{array}{l}\text { Okhotsk } \\
\text { Sea }\end{array}$} & $\begin{array}{l}\text { offshore Para- } \\
\text { mushir island }\end{array}$ & $\begin{array}{l}74.0 \\
97.9\end{array}$ & $\begin{array}{l}99.9 \\
99.9\end{array}$ & $\begin{array}{r}<0.03 \\
0.05\end{array}$ & $\begin{array}{l}\text { n.a. } \\
\text { n.a. }\end{array}$ & $\begin{array}{l}\text { n.a. } \\
\text { n.a. }\end{array}$ & $\begin{array}{l}\text { n.a. } \\
\text { n.a. }\end{array}$ & $\begin{array}{l}\text { n.a. } \\
\text { n.a. }\end{array}$ & $\begin{array}{l}0.07 \\
0.09\end{array}$ & $\begin{array}{l}-67.3 \\
\text { n.a. }\end{array}$ & $\begin{array}{l}\text { n.a. } \\
\text { n.a. }\end{array}$ & $\begin{array}{l}\text { n.a. } \\
\text { n.a. }\end{array}$ & $\begin{array}{l}\text { n.a. } \\
\text { n.a. }\end{array}$ \\
\hline & $\begin{array}{l}\text { offshore } \\
\text { Sakhalin } \\
\text { island }\end{array}$ & 96.2 & $\begin{array}{l}99.3 \\
97.0\end{array}$ & $\begin{array}{l}<0.03 \\
<0.03\end{array}$ & n.a. & n.a. & n.a. & n.a. & 0.63 & $\begin{array}{l}-64.3 \\
-59.6 \\
-61.6\end{array}$ & n.a. & n.a. & n.a. \\
\hline
\end{tabular}

n.a. = not analyzed

n.d. = not detected

breccias was up to 35 vol\%. This high content may be attributed to the contrasting rates of ascending hydrateforming fluids and mineral mass. Fluids ascend more rapidly than volcanic mud. Hydrates present at the sea bottom occur by the same process.

The gas from hydrate samples contains as much as $19.3 \%$ ethane and $2.4 \%$ propane (Table 1 ). The high content of methane homologues and the heavy isotopic composition of carbon in the methane-ethane-propanebutane series $\left(\delta^{13} \mathrm{C}\right.$ values for the sample from Buzdag are $-44.8 \%,-26.0 \%,-22.1 \%$ and $-20.9 \%$, respectively) attest to the catagenic nature of the gas. Gas hydrates in the clay breccia coexist with very salty pore water. The chlorinity of the interstitial water is locally ten times as much as that of the Caspian bottom water (i.e. $5.6 \mathrm{~g} / \mathrm{l})$. Hence, gas hydrates are formed from mud vol-

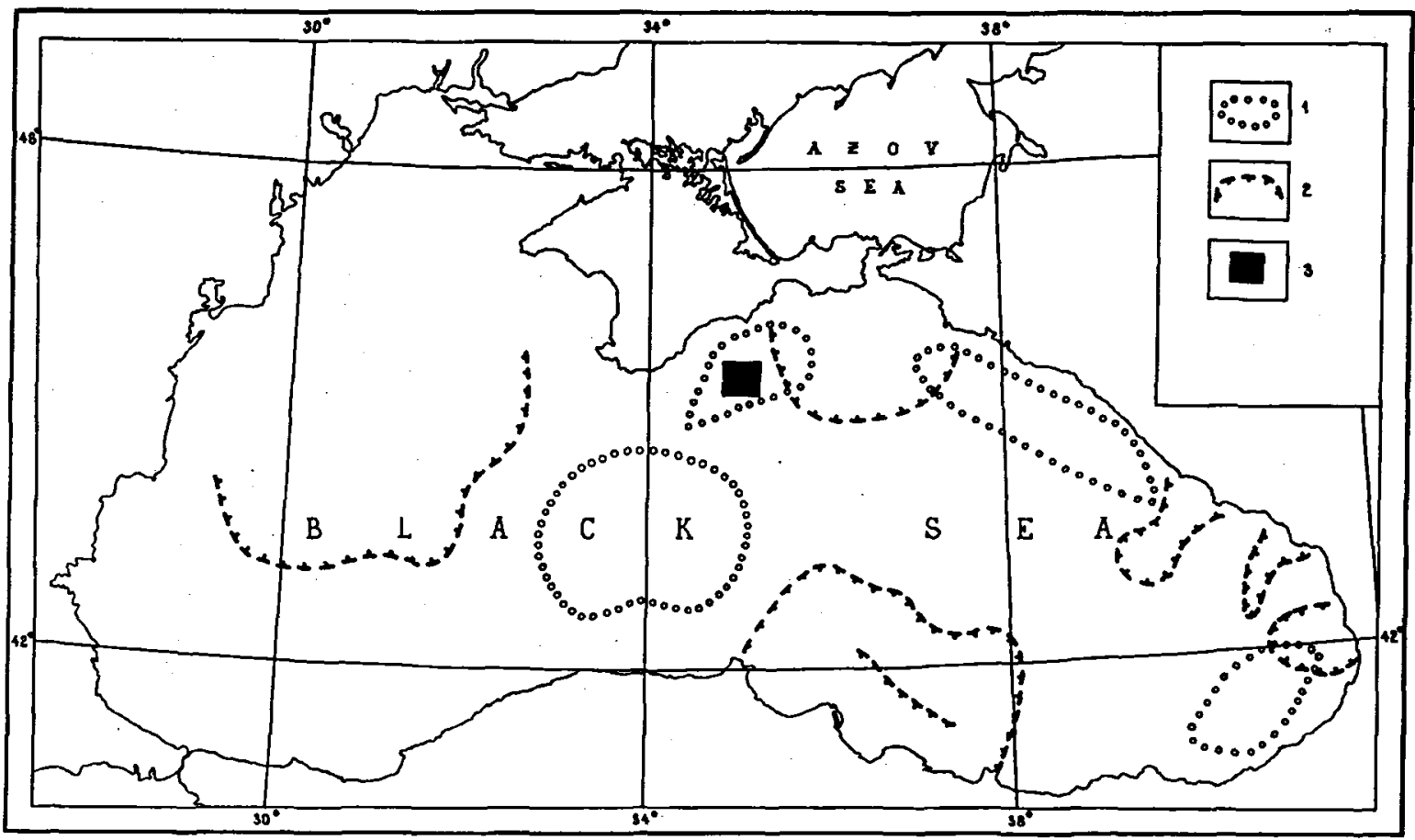

Fig. 6. Gas hydrates and diapirs in the Black Sea. 1 - boundary of diapir distribution zones, 2 - boundary of submarine deltas and fan deltas, 3 - study area (gas hydrate locations in the Feodosia region).

Soloviev \& Ginsburg: Formation of submarine gas hydrates 
canic brine and the accumulation of gas hydrates is associated with mud volcanoes and depends on the movements of fluids.

\section{The Black Sea}

The gas hydrates in the Black Sea were discovered on the lower part of the Crimean continental slope at a depth of $2050 \mathrm{~m}$ (Ginsburg et al. 1990)(Fig. 6) where gas hydrate accumulation is associated with diapiric structures and mud volcanoes (Fig. 7). The hydrates were found both in clay breccia, where they formed inclusions ranging from dispersed to massive, and in deformed silt-clay sediments where the hydrates were observed as thin plates.

Methane is the main component of the Black Sea hydrates (see Table 1). The water responsible for gas hydrate formation is of a lower salinity than sea water. Its composition is similar to that of the mud volcanic waters in the Kerch-Taman region. The $\delta^{13} \mathrm{C}$ values of methane from gas hydrates measured in two samples are $-61.8 \%$ and $-63.4 \%$ which is typical of mud volcanic gases from the same region. Hence, the hydrate-forming fluids offshore from the Crimea must have come from the deep sedimentary cover and the gas hydrate formation is due to infiltration.

\section{The Okhotsk Sea}

Gas hydrate accumulations connected with submarine gas seepage plumes were discovered and investigated over two areas of the Okhotsk Sea (Ginsburg et al. 1992) (Fig. 8). The locations of submarine seepages are easily detected using echo sounding (Fig. 9) and coincide with fracture zones. Eleven gas plumes were identified in the Okhotsk Sea, one plume near Paramushir Island at a depth about $800 \mathrm{~m}$ and ten plumes on the continental slope off Sakhalin Island at depths of 620 to $1040 \mathrm{~m}$. Gas hydrate-bearing sediments were recovered in both regions at subbottom depths of $0.3-1.2 \mathrm{~m}$.

The hydrate cores obtained near Sakhalin Island showed subhorizontal lenticular-bedded structure caused by hydrates. The water content in the hydrate-bearing sediments ranged from 65 to $66 \%$ in contrast to $48 \%$ to $60 \%$ in the overlying sediments. We consider that the subhorizontal structure and specific water distribution near the upper boundary of the hydrate-bearing sediments are brought about by the formation of hydrates from upward diffusing methane whilst water moved in the opposite direction to the front of the reaction.

All the gas hydrate occurrences in the Okhotsk Sea are associated with carbonate cementation of the sediments. Many carbonate concretions were observed together with hydrates and allochthonous calcium carbonate deposits were noted on mollusc shells. These features are quite normal under gas seepage conditions. The carbonate concretions are the result of methane oxidation which saturates the pore water with carbon dioxide; calcium carbonate is then precipitated (Zonenshain et al. 1987).

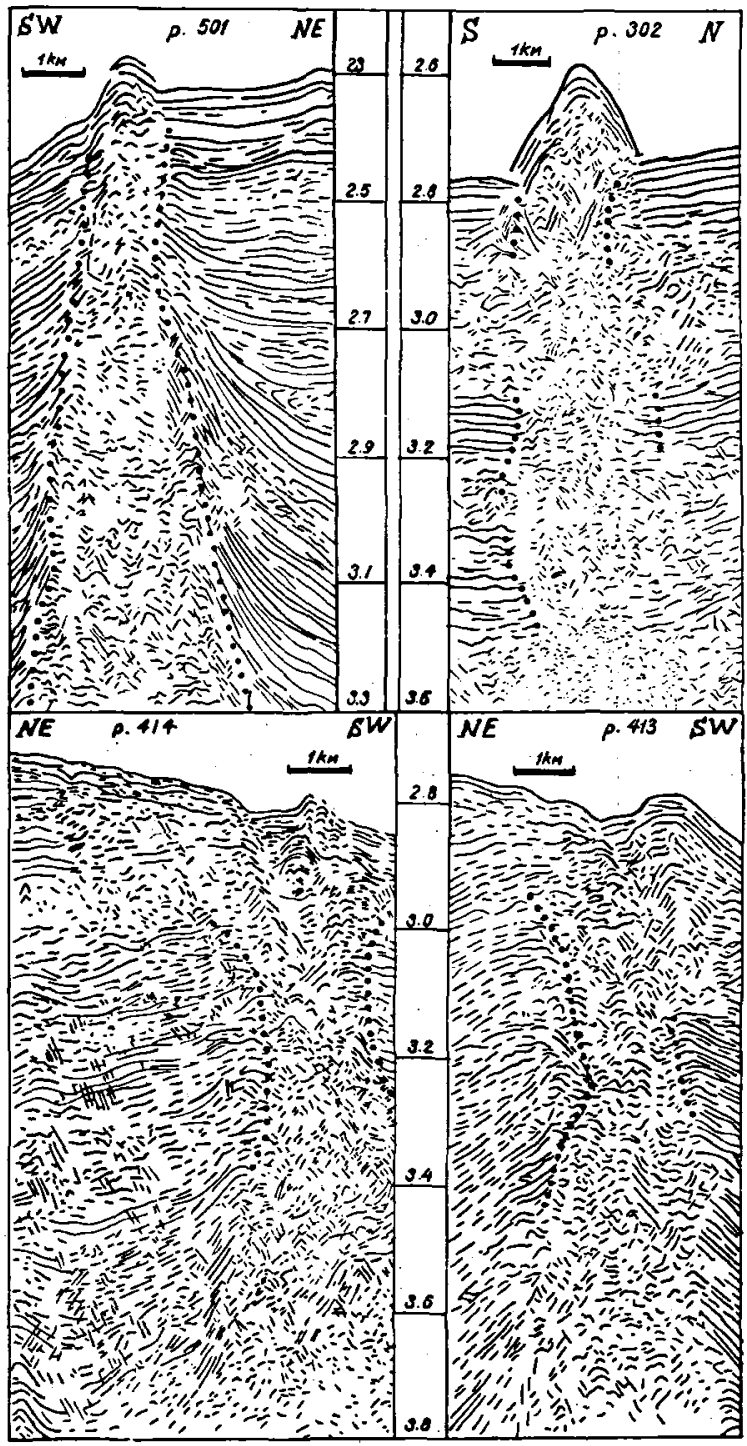

Fig. 7. Seismic profile across diapirs in the Black Sea, Feodosia region. Dotted lines are diapir limits; figures on the vertical scales are two-way traveltime (s).

According to the data from deep seismic and continuous seismic profiling, the area of fluid discharge near Paramushir Island coincides with a high of the acoustic basement. The loss of definition and the pull-down of reflectors are presumably attributable to low seismic velocity in this part of the sedimentary sequence. This is most probably associated with the occurrence of gascharged sediments above the acoustic basement. The submarine fluid seepage fields off Sakhalin Island are in the zone in which there are numerous submeridianal faults along the west side of the Deriugin Basin near the oil and gas areas of Sakhalin Island and the adjacent shelf. These faults are most likely conduits for migrating gas as is 
Fig. 8. Study areas in the Okhotsk Sea.

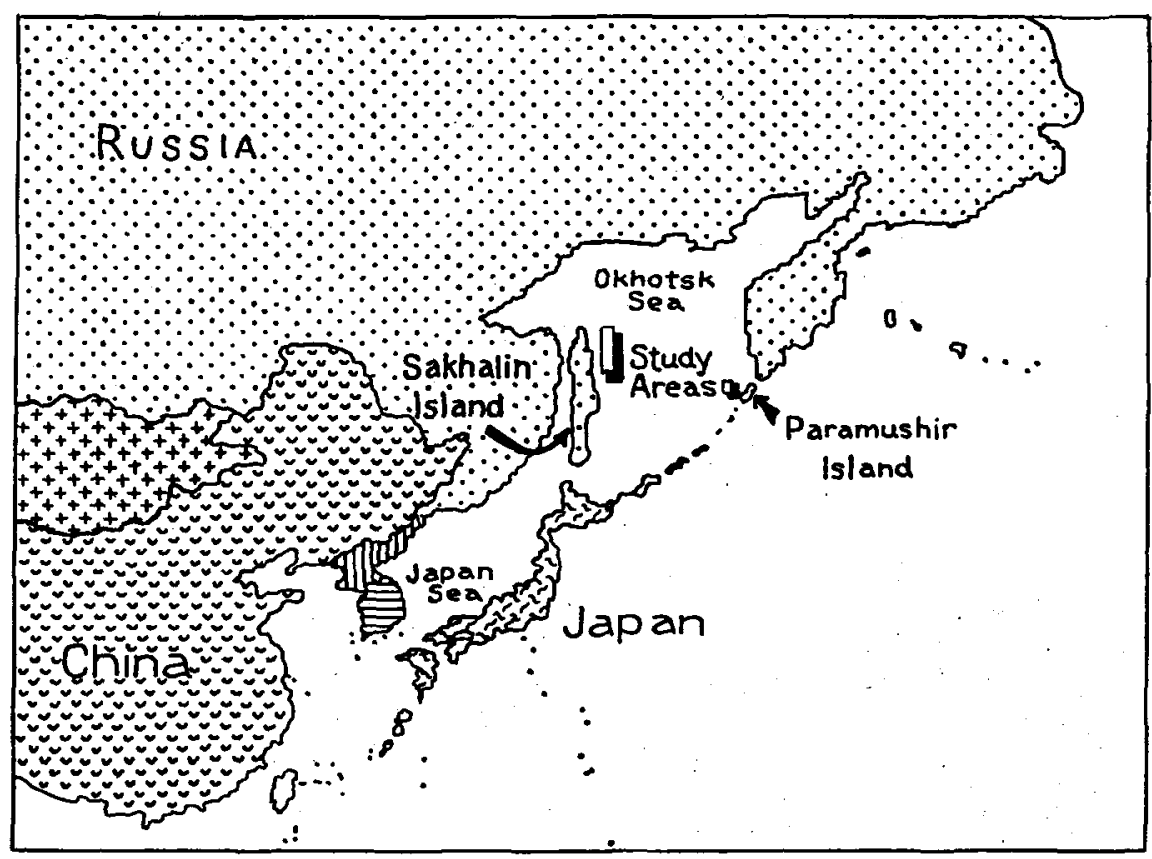

Fig. 9. Echo sounding anomalies associated with submarine gas discharge and gas hydrate locations. A offshore Sakhalin Island, B - offshore Paramushir Island.

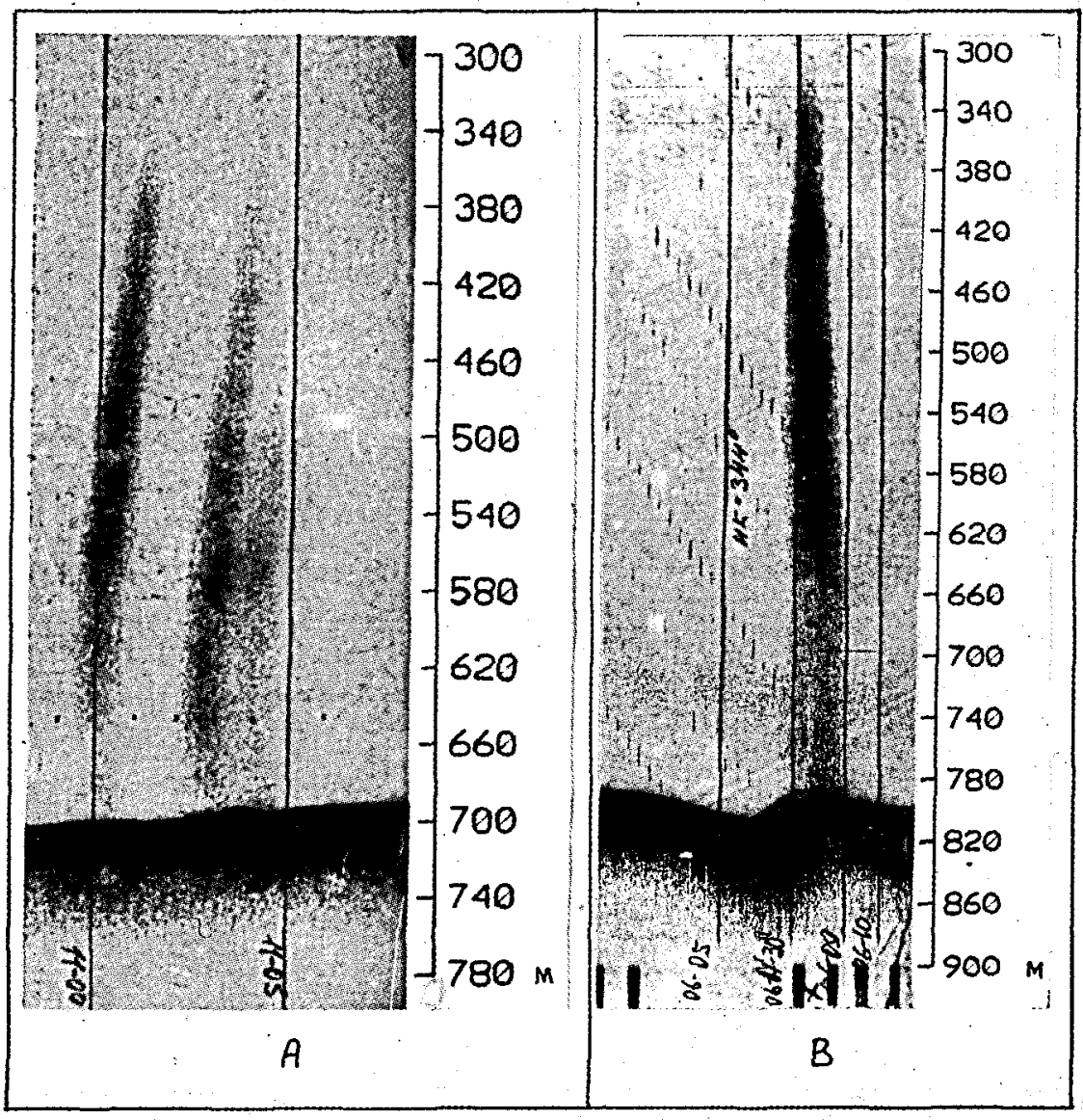




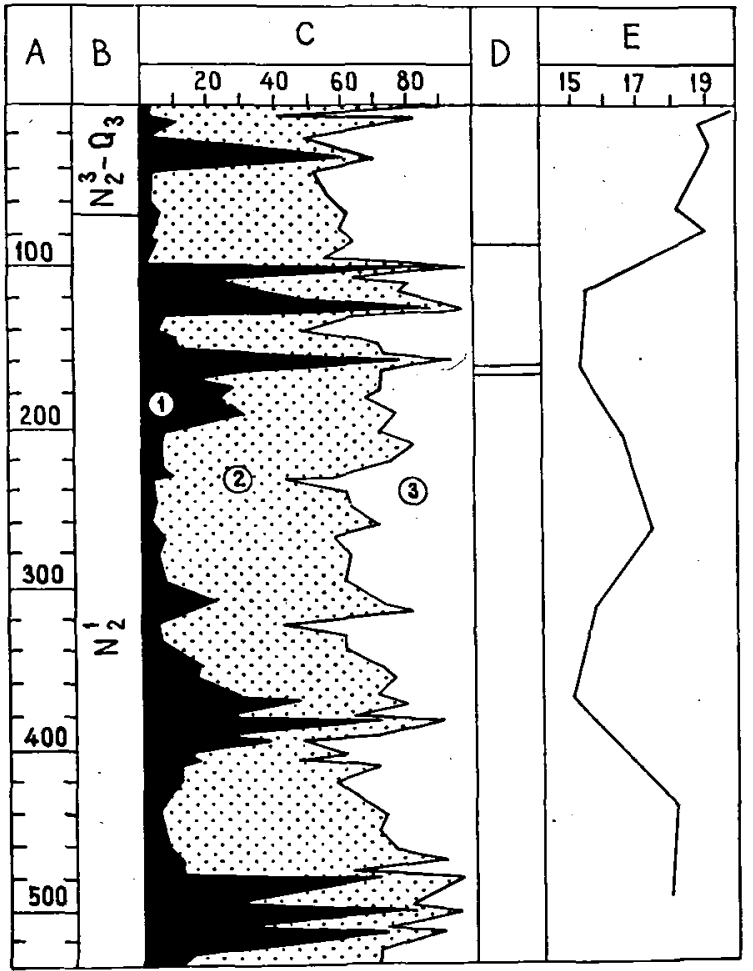

Fig. 10. Lithological and hydrogeochemical control of gas hydrate locations, Site 491 DSDP, offshore Mexico (Initial Reports..., 1982). A - subbottom depth, $\mathrm{m}$; B - geological age; C particle size distribution, \% (1 - sand, 2 - silt, 3 - clay); D - gas hydrate locations; $\mathrm{E}-$ chlorinity of pore water, $\%$.

indicated by the seismic evidence of gas-charged sediments.

\section{Other locations}

Data on gas hydrates recovered by bottom sampling in the Gulf of Mexico (Brooks et al. 1984) and offshore North California (Brooks et al. 1991) also prove that gas hydrate occurrences are associated with submarine fluid seepage areas and, in particular, with mud volcanoes. According to the deep-sea drilling data, the holes that recovered hydrate-containing sediments (Legs 66, 67, 76, $84,96,112,127,131$ and 146 DSDP-ODP) show a certain lithological control of gas hydrates. Normally their occurrences are associated with relatively porous ash and silty sands (Fig. 10) as well as fracture zones (Fig. 11).

All the areas where gas hydrates have been discovered in the course of deep-sea drilling are characterized by specific geological and hydrogeological settings in which fluids are squeezed from the sediments. This may be either by mere simple consolidation (e.g. Blake Outer Ridge area) or by tectonic overpressure in subduction zones (deep water trenches). The slope of the Middle
American Trench is a typical example. On seismic profiles, the distinct landward-dipping reflectors (LDR) may indicate the routes of squeezed gas-bearing fluids migrating to the gas hydrate formation zones (Fig. 12). Widespread bottom simulating reflectors (BSR) identified as the base of gas hydrate-bearing sediments (Shipley et al. 1979) are indicative of gas hydrate formation also involving upward migrating gas-bearing fluids.

\section{Discussion and conclusions}

Generally, the presented data support the assumption that fluid infiltration is the major hydrate-forming process in the submarine environment. This may be observed at different scales - from individual specimens to worldwide localities.

1. Comparatively permeable lithological horizons and fractures are present in hydrate-bearing intervals of ocean drilling holes. The structures of hydrate-containing sediments also suggest that hydrates should form by moving fluids and should be associated with faults. Gas hydrates fill fractures and large voids and cement comparatively coarse-grained sediments.

2. In regions with hydrates, it is possible to establish a direct relationship or spatial link between hydrate occurrences and geological structures which may control the movements of fluids towards the sea bottom. These are faults, diapirs, mud volcanoes, crests of anticlines, layered sequences and updipping reflectors probably caused by bedding or fracturing.

3. Hydrate occurrences are restricted to continental margins and to intra-continental and marginal seas. Submarine seepages (of various origins) and pockmark areas coincide with the same worldwide structures. This is well illustrated by the map of gas hydrate

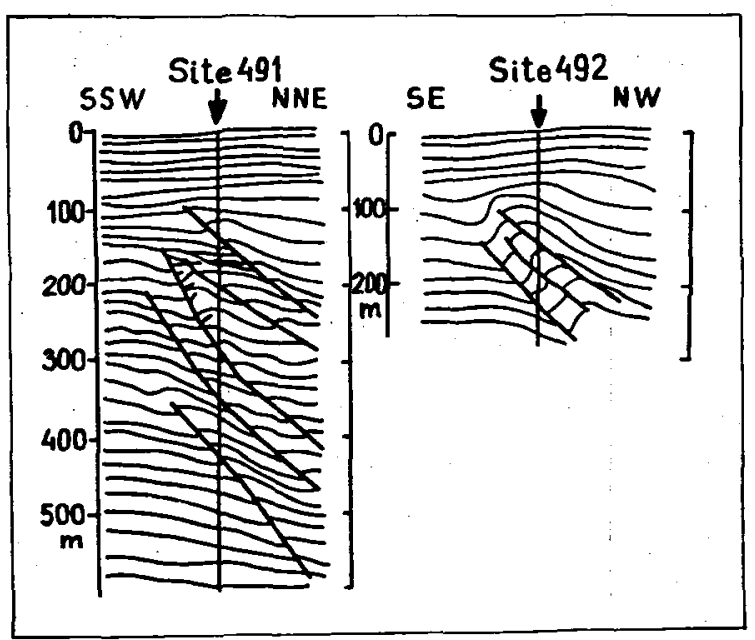

Fig. 11. Fractures in hydrate-containing site sections according to paleomagnetic data, offshore Mexico (Initial Reports..,1982). 
Fig. 12. Characteristic seismic reflectors which are presumed to be fluidconductors in hydratebearing region, Middle American Trench, offshore Mexico (Initial Reports..., 1982, 1985). BSR - Bottom Simulating Reflection; LDR - Landward Dipping

Reflection; 486-492 - DSDP Sites.

locations in the oceans (see Fig. 1) and the map of pockmark and seepage distribution (Hovland and Judd 1988: Fig. 4.73).

Gas hydrates in the submarine environment may be formed both from water-dissolved gas and from free gas. The formation of gas hydrates in these contrasting situations is substantially different (Fig. 13). Water has an important advantage over gas. Dissolved salts, concentrated as a result of the transformation of the water fraction into hydrate, are removed by filtering the flow. In the case of gas infiltration, salts remain in the reaction zone and inhibit the process. Hydrate films forming at the gas-water interface are also inhibitors. Thus, the kinetics of hydrate formation from free gas are evidently characterized by the fact that diffusion plays a significant role. In the vicinity of an ascending flow of gas-saturated water, the reaction zone seems to be located where gas hydrates are forming from diffusing gas.

Natural gas hydrates derived from gas-saturated infiltrating water are likely to be the most common. The most significant hydrate-forming infiltration takes place under the conditions in which pore water is released from sediments by geostatic pressure and tectonic overpressure. A similar model has been recently developed by Hyndman (1990) on the basis of seismic survey data (BSR). In this model, gas hydrates form from pore fluids that are ex- pelled from an accretionary wedge. Another cause of water infiltration might be thermo-artesian pressure forming under local heating from a magma chamber or a cooling intrusion. Sediments heated in this way may generate hydrocarbon gases.

Thus, gas hydrates form mainly from fluids infiltrating towards the sea floor through or from a thermobaric hydrate stability zone. This zone appears to act as an ocean-wide gas-geochemical barrier.

\section{Dansk sammendrag}

Det foreliggende arbejde beskriver forekomsten af gashydrater og deres kemiske sammnensætning fundet i Sortehavet, det Kaspiske Hav og i det Okhotske Hav.

Dannelsen af gashydrater er et almindeligt forekommende geologisk fænomen $i$ det submarine miljø i forbindelse med relativt dybt vand (500-2000 meter). Gashydrater findes som regel på kontinentalskråninger og i marginale eller intra-kontinentale have, ofte $\mathrm{i}$ forbindelse med sedimentære bassiner med et relative tykt dakke af hurtigt akkumulerende unge sedimenter. Årsagen til dannelsen af gashydrater er imidlertid kun dårlig kendt.

Gashydrater dannes almindeligvis udfra opløst gas i formationsvandet, men laboratoriefors $\emptyset \mathrm{g}$ tyder på, at gashydrater også kan dannes i forbindelse med fri gas. Gas-
Fig. 13. Gas hydrate formation zones and fluid migration in vicinity of seabed seepages of gassaturated water (A) and free gas (B). 1 - fluid-conducting zone, 2 - main direction of fluid flow, 3 - zone of hydrate formation by precipitation from filtering water, 4 - zone in which diffusion is sufficient to lead to the formation of concretionary hydrates, 5 zone of gas-undersaturated water, 6 - direction of diffusion flow of dissolved gas, 7 - opposite direction of water flow into the hydrate formation zone.

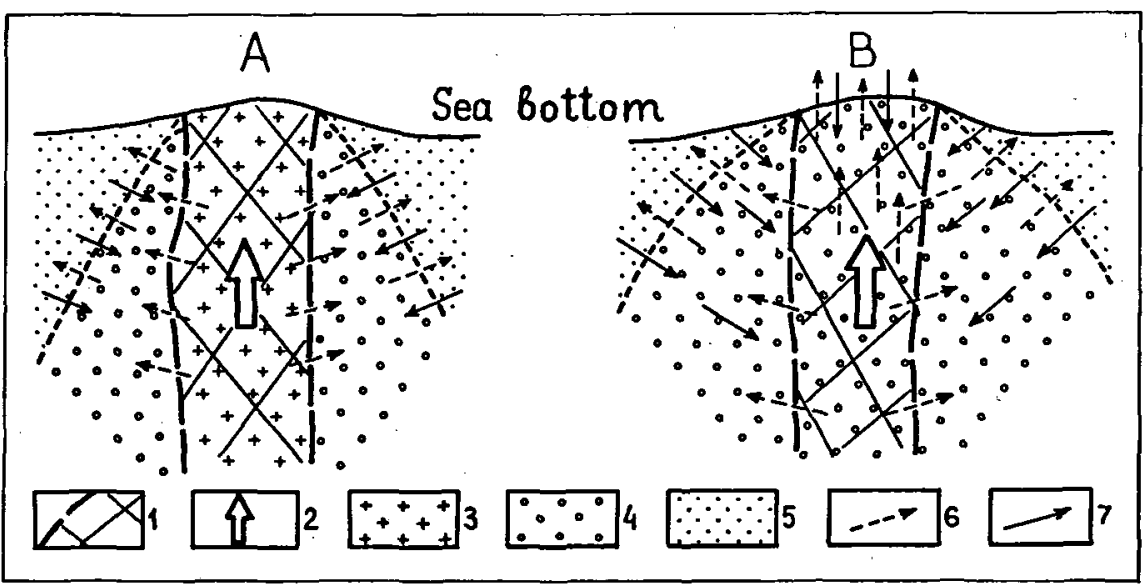


hydrater findes overvejende i porøse og permeable overfladenære sedimenter, og de geologiske forhold tyder på, at deres dannelse er betinget af infiltration af gasholdigt formationsvand fra dybere liggende lag. Forekomsten af gashydrater er således som regel forbundet med andre gasrelaterede geologiske fænomener så som submarine gasudslip, mudder vulkaner, pockmarks og gasmættede sedimenter. Disse overfladenære fænomener kan ofte relateres til dybere liggende geologiske strukturer, som f.eks. forkastninger og diapirer, som kan være den udløsende årsag til migration af fri gas eller gasmættet formationsvand til de overfladenære sedimenter og dermed dannelsen af gashydrat.

\section{References}

Brooks, I. M., Field, M. E. \& Kennicutt, M. C. II 1991. Observations of gas hydrates in marine sediments, offshore Northern California. Marine Geology 96: 103-109.

Brooks, J. M., Kennicutt, M. C. II, Fay, R. R., McDonald, T. J. \& Sassen, R. 1984. Thermogenic gas hydrates in the Gulf of Mexico. Science 225, 4660: 409-411.

Efremova, A. G., Gritchina, N. D., Kulakova, L. S., Rateev, M. A. \& Turovsky, D. S. 1979. About discovery of the gas hydrates on the bottom of Southern Caspian Sea. EI VNIIEGasprom, seria: Geologia, burenie i razrabotka gasovykh mestorozhdeniy, 21, Moskwa: 12-13 (in Russian).

Efremova, A. G. \& Zhizhchenko, B. P. 1974. Discovery of gas hydrates in sediments of recent aquatoriums. Doklady Akademii Nauk SSSR 214, 5: 1129-1130 (in Russian).

Ginsburg, G. D., Gramberg, I. S., Guliev, I. S. Guseinov, R. A. Dadashev, A. A., Ivanov, V. L., Krotov, A. G., Muradov, Ch. S., Soloviev, V. A. \& Telepnev, E. V. 1988. Subaquatic mud-volcanic type of gas hydrate accumulations. Doklady Akademii Nauk SSSR 300, 2: 416-418 (in Russian).

Ginsburg, G. D., Kremlev, A. N., Grigor'ev, M. N., Larkin, G. V., Pavlenkin, A. D. \& Saltykova, N. A. 1990. Filtrogenic gas hydrates in the Black Sea (twenty-first voyage of the research vessel "Evpatoriya"). Soviet geology and geophysics (Geologiya i Geofizika) 31, 3, Allerton Press: 8-16.

Ginsburg, G. D., Soloviev, V. A., Cranston, R. E., Lorenson, T. D. \& Kvenvolden, K. A. 1993. Gas hydrates from the continental slope, offshore Sakhalin Island, Okhotsk Sea. GeoMarine Letters 13: 41-48.

Harrison, W. E. \& Curiale, J. A. 1982. Gas hydrates in sediments of holes 497 and 498A, Deep Sea Drilling Project Leg 67. Initial Reports of the Deep Sea Drilling Project 67, Washington D.C., U.S. Government Printing Office: 591-594.

Hovland, M. \& Judd, A. G. 1988. Seabed pockmarks and seepages. Impact on geology, biology and the marine environment. Graham \& Trotman, London/Dordrecht/Boston.
Hyndman, R. D. 1990. A test of a model for the formation of methane hydrate and seafloor bottom simulating reflectors by drilling on the northern Cascadia subduction zone. Proceedings of the second Canadian ODP Proposals Workshop, Feb. 22-24, 1990: YII-2-YII-9.

Initial Reports of the Deep Sea Drilling Project 1982 66, Washington D.C., U.S. Government Printing Office.

Initial Reports of the Deep Sea Drilling Project 1985) 84, Washington D.C., U.S. Government Printing Office.

Initial Reports of the Deep Sea Drilling Project 198696 Washington D.C., U.S. Government Printing Office.

Kvenvolden, K. A. \& Barnard, L. A. 1983. Gas hydrates of the Blake Outer Ridge Site 533, DSDP/IPOD Leg 76. Initial Reports of the Deep Sea Drilling Project 76, Washington D.C., U.S.Government Printing Office: 353-365.

Kvenvolden, K. A. \& Kastner, M. 1990. Gas hydrates of the Peruvian outer continental margin. In Suess E., von Huene R., et al.1990. Proc. ODP, Sci.Results, 112, College Station, TX (Ocean Drilling Program): 517-526.

Kvenvolden, K. A. \& McDonald, T. J. 1985. Gas hydrates of the Middle America Trench - Deep Sea Drilling Project Leg 84. Initial Reports of the Deep Sea Drilling Project 84, Washington D.C., U.S. Government Printing Office: 667-682.

Makogon, Yu. F. \& Davidson, D. V. 1983. Affect of excessive pressure on the stability of methane hydrate. Gazovaya Promyshlennost' 4: 37-40 (in Russian).

Mashirov, Yu. G., Stupin, D. Yu., Ginsburg, G. D. \& Soloviev, V. A. 1991. Experience of hydrate formation by dissolved gas. Doklady Akademii Nauk SSSR 316, 1: 205-207 (in Russian).

Namiot, A. Yu. \& Gorodetskaya, A. I. 1969. Alteration of gas saturation of water under the cooling. Gazovaya Promyshlennost' 11: 20-22 (in Russian).

Shipboard Scientific Party 1990. Site 796. In Tamaki, K., Pisciotto, K., Allan, J. et al., Proc. ODP, Init.Repts. 127, College Station, TX (Ocean Drilling Program): 247-322.

Shipboard Scientific Party 1991. Site 808. In Taira, A., Hill, I., Firth, J. V., et al., Proc. ODP, Init.Repts. 131, College Station, TX (Ocean Drilling Program): 71-269.

Shipley, T. H. \& Didyk, V. M. 1982. Occurrence of methane hydrates offshore Southern Mexico. Initial Reports of the Deep Sea Drilling Project 66. Washington D.C., U.S.Government Printing Office: 547-555.

Shipley, T. H., Houston, M. H., Buffler, R. T., Shaub, F. J., McMillen, K. J., Ladd, J. W. \& Worzel, J. L. 1979. Seismic reflection evidence for widespread possible gas hydrate horizons on continental slopes and rises. AAPG Bull. 63: 22042213.

Zonenshain, L. P., Murdmaa, I. O., Baranov, B. V., Kuznetsov, A. P., Kuzin, V. S., Kuz'min, M. I., Avdeiko, G. P., Stunzhas, P. A., Lukashin, V. N., Barash, M. S., Valjashko, G. M. \& Demina, L. L. 1987. Subaqueous gas seepage in the Okhotsk Sea off west Paramushir Island. Okeanologia 27, 5: 795-800 (in Russian). 